\title{
Japan-Nepal Joint Student Himalayan Exercise Program 7 Years
}

\author{
Masaru Yoshida ${ }^{1,2, *}$, Kazunori Arita ${ }^{3}$, Tetsuya Sakai ${ }^{4}$, Bishal Nath Upreti ${ }^{1,5,6}$ \\ ${ }^{1}$ Gondwana Institute for Geology and Environment, Hashimoto, Japan \\ ${ }^{2}$ Department of Geology, Tri-Chandra Campus, Tribhuvan University, Kathmandu, Nepal \\ ${ }^{3}$ Hokkaido University Museum, Sapporo, Japan \\ ${ }^{4}$ Faculty of Interdisciplinary Science and Engineering, Shimane University, Matsue, Japan \\ ${ }^{5}$ Nepal Academy of Science, Kathmandu, Nepal \\ ${ }^{6}$ Department of Geology, School of Mines, University of Zambia, Lusaka, Zambia
}

Copyright $\odot 2019$ by authors, all rights reserved. Authors agree that this article remains permanently open access under the terms of the Creative Commons Attribution License 4.0 International License

\begin{abstract}
A geotraverse connecting the Kaligandaki and the Tinau rivers via Pokhara in Western Nepal covers all geologic zones of the Himalayan Orogen from the Tethys Himalayan Zone in the north to the Gangetic Plain in the south. The Student Himalayan Exercise Program has aimed to conduct tours of the above geotraverse, provided for Japanese and Nepalese students. The preparation of the program started in 2008, and the practical content of the tour was decided in December 2010 by collecting ideas from several Himalayan geologists in Japan and Nepal and receiving consent of 17 geoscience-related university departments, committing them to give education points for the participation in the exercise, or to examine the possibility of it. After collecting ideas from and sending call-for-participants to geoscience-related departments of over 60 Japanese universities, and after negotiations with several Nepalese trekking agencies, the first Student Himalayan Exercise Tour (SHET) was conducted in March 2012. Since then the exercise tour was conducted every year in March. We are convinced that the SHETs throughout all 7 years (2012-2018) were successful and meaningful, and we therefore suggest that the program should continue further in future.
\end{abstract}

Keywords Himalayan Field Exercise, Student Field Geo-exercise, Himalayan Geo-exercise, Himalayan Geotour, Kaligandaki Geotour

\section{Introduction}

To see geology in the field, to observe the occurrences of rocks at outcrops and to touch and collect rocks in the field, are fundamentally required to students, educators, and researchers of geology. The experience of working with field geology is essential for the whole range of geoscientists.

We believe that every geoscientist should have the experience of geological field survey and of forming a geologic map by himself from his field survey. Without that, he can neither get the true understanding of geological reports by others, nor can make valuable research results that carry usable facts and could be utilized in long future times.

It is a pity, however, that field geology is fading from university curriculum, and further, teachers who teach field geology to students are becoming increasingly rare at the universities. We have been conducting student geo-exercise tours in the Himalaya for seven years since 2012, expecting that students who participated in the tour will become familiar to field geology and some of them will be encouraged to further utilize the field geology in their future work, and further would encourage the geology world to popularize field geology.

The Himalaya is one of the largest mountain ranges on the earth. Reflecting the collisional tectonics of Indian and Eurasian plates, the Himalaya exhibits a clear geologic constitution. Five geotectonic zones ranging in age from the Proterozoic to the Quaternary are arranged parallel to the mountain range as explained by Yoshida and Ulak (2017). A large uplifting rate of $5 \mathrm{~mm} / \mathrm{y}$ still continuing today results in forming deep valleys and steep mountain slopes where slope collapse, debris flow, landslides and glacial lake outburst flood (GLOF) are often taking place. The Himalaya is the living museum for people studying geoscience and natural hazards.

All the situations and ideas above prompted us to start and continuously conduct the Student Himalayan Exercist Tour (SHET-HP, 2018). 


\section{Inauguration of the Program}

For 2 years from 2003 to 2005, one of the authors (MY) worked at the Department of Geology, Tri-Chandra Campus, Tribhuvan University in Kathmandu, Nepal. During these years, MY joined several times to the student exercise camps of the Department in the Himalaya and trained students in collaboration with teachers of the Department especially often with one of the authors (BNU) who invited MY to the Department. During the field exercise, MY and BNU realized that it would be fantastic to bring Japanese students to the Nepal Himalaya for an exercise tour.

From 2004 to 2011, MY published 5 geoguidebooks including of Kaligandaki area, Everest region, Langtang valley and NW Himalaya, and he led Japanese groups to those areas, in collaboration with several TU staff including BNU. Through preparation and fulfillment of these geotours (Yoshida et al., 2008), know-how and improvements for the Himalayan geotours were gathered.

After making a variety of efforts over the years, a group named Student Himalayan Exercise Project was formed, who started preparation for the student Himalayan Exercise Program (SHET program) in 2011. We decided to utilize the geoguidebook (Upreti and Yoshida, 2005) for the section Tatopani-Mukutinath along the upper reaches of the Kaligandaki valley, and newly prepared a simple geoguide leaflet for the section Pokhara-Tatopani and Kathmandu-Pokhara-Butwal-Mugling. In 2014, the above guidebook was revised (Yoshida and Upreti, 2014). In 2017, we formed a new guidebook assembling all guidebooks into one book (Yoshida and Ulak, 2017) for convenient usage by the SHET.

A variety of ideas on the contents of the exercise tour was collected from about 30 Japanese and Nepalese geoscientists who have been studying Himalaya. We also collected ideas from earth science-related departments of 60 Japanese universities on the appropriate time for the exercise tour. We analysed these ideas above, received consent of 30 Japanese and Nepalese geoscientists who have been familiar to the Himalayan geosciences to register as the candidate to work as a leader of the exercise tour, and collected nominal support from 6 academic societies of Japan and Nepal as well as from 34 senior scientists of Japan. After synthesizing various issues above the SHET program, including the plan of the exercise tour (SHET) in west-central Nepal Himalaya, the tour project was settled and started in 2012.

\section{Preparation for the Tour}

Through the above effort, the exercise tour (SHET) course Kathmandu- Pokhara- Muktinath- PokharaLumbini- Mugling- Kathmandu with a duration of 13 days in March was settled. We decided that the SHET should be safe, but within a reasonable economy. To lessen the cost of participation for the tour, the best Nepal trekking company was identified, collecting and assessing several quotations from Nepalese companies.

Advertisement of call-for-participants (Fig. 1) was sent to almost all geoscience-related department of Japanese universities as well as Antarctic and Gondwanan geologists in Japan and requested their collaboration to advertise the SHET program. The advertisement appeared not only in newsletters of some supporting societies including the Geological Society of Japan but also on the home page of the Gondwana Institute for Geology and Environment.

Through the advertisement, in March 2012, the SHET-1 received a group participation of 7 students and a teacher (one of the authors, T.S.) from the Shimane University, and in addition, individual 5 students from several universities in Japan, resulting in 12 participants in total by the end of November 2011.

After November until the end of February next year, several communications including the distribution of a geotour guidebook and leaflets to participants and an encourage of pre-study the book, and informations about tour conditions, including the danger of the Himalayan geotour and measures for them were dispatched to participants. Instructions for vaccination against dangerous diseases such as tetanus and rabies, and messages about altitude sickness, etc. were additionally addressed. With the above communications, participants came to face the departure of the tour with almost no troble and worry. 


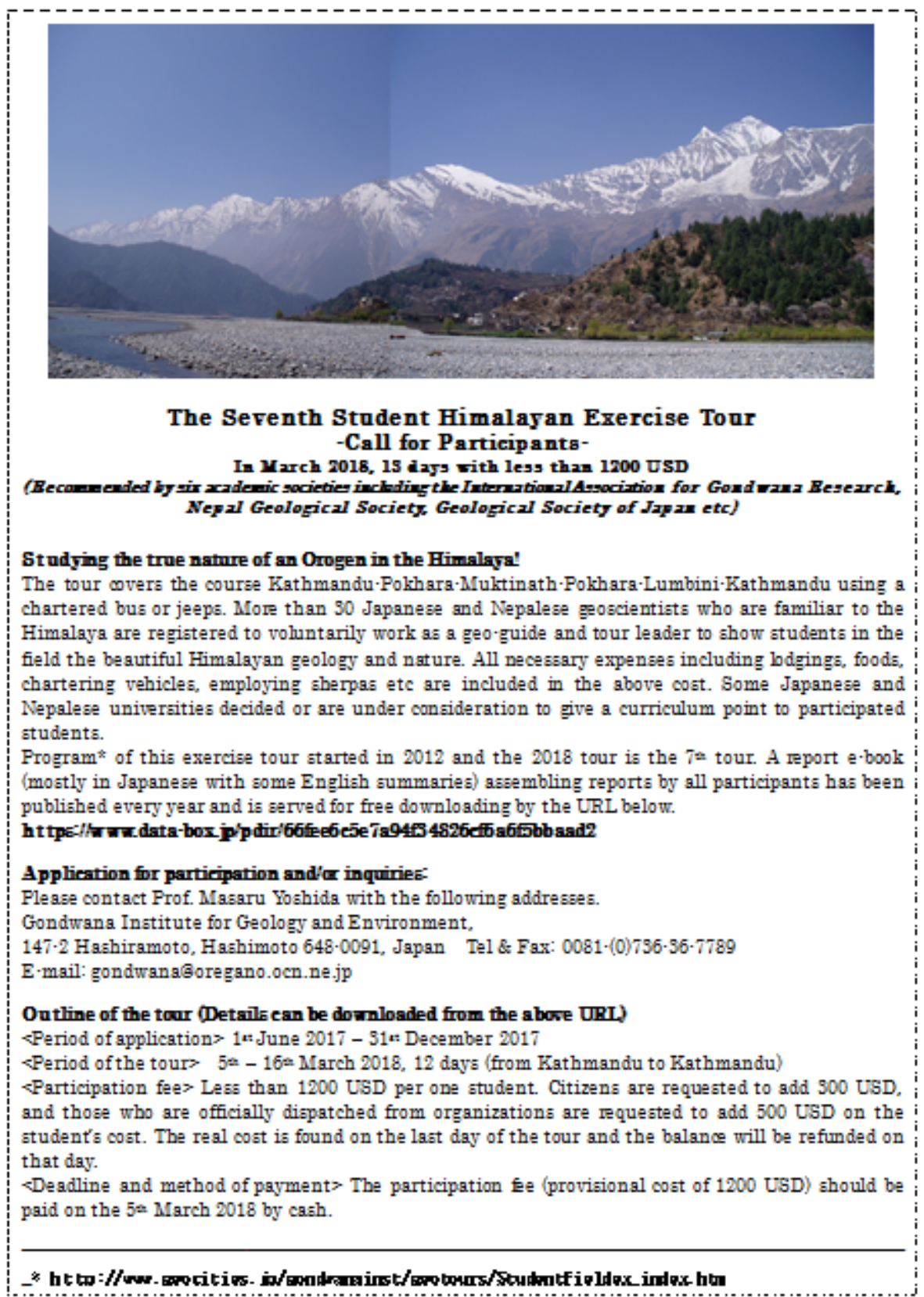

Figure. 1. A leaflet, Call-for-participants to SHET-7.

\section{Himalayan Geology and the SHET Geotour Course}

The Himalaya formed by the collision of the Indian and
Eurasian Plates since ca $50 \mathrm{Ma}$. The geologic constitution of the Himalayan Orogenic Belt comprises five geotectonic zones running parallel to the mountain range (Fig.2). The geotectonic zones evidently reflects the collision tectonics as explained by Yoshida and Ulak (2017). 


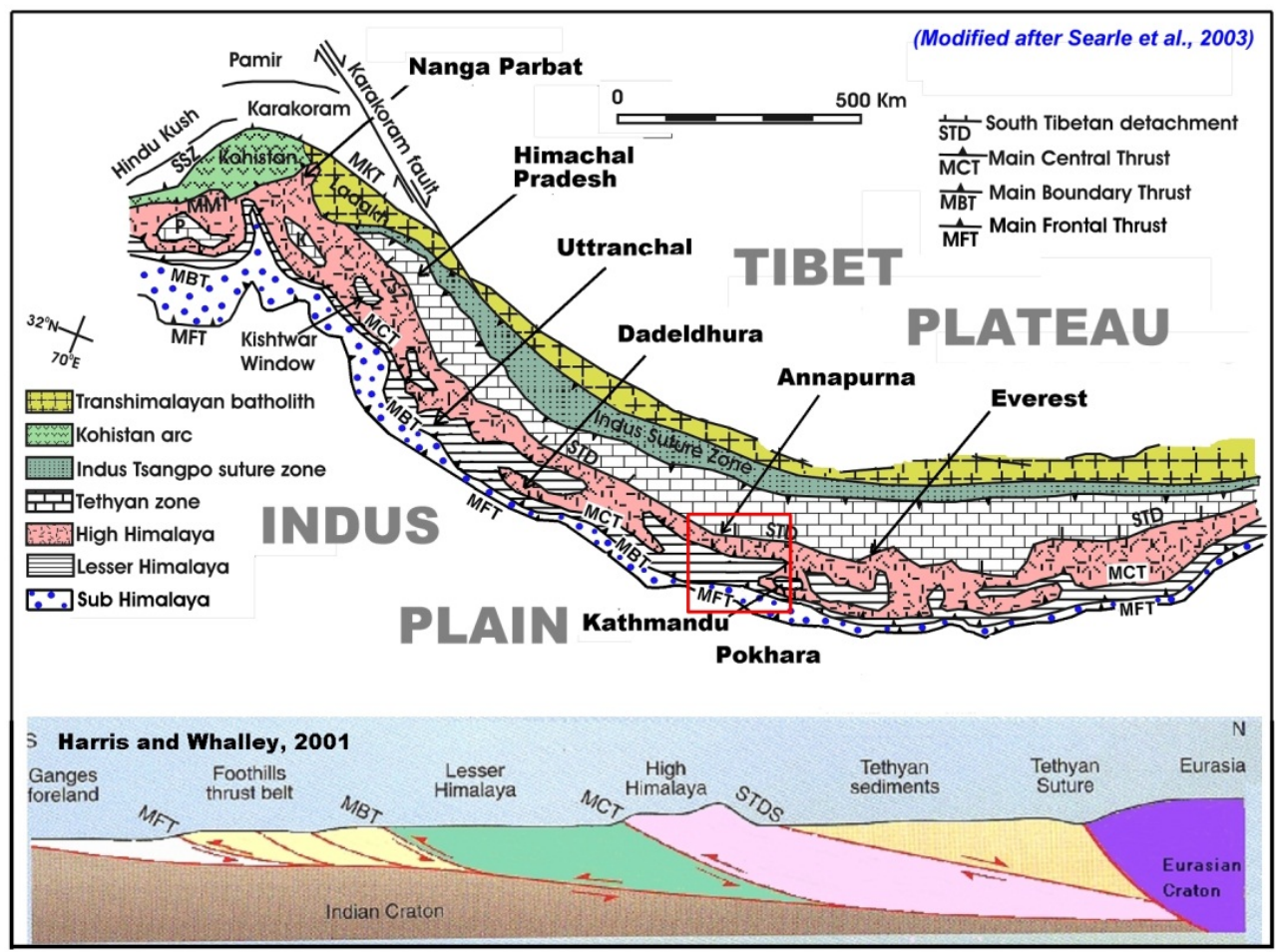

(Base geologic map is derived from Searles et al., 2003).

Figure 2. Geologic outline of the Himalaya and the SHET study area.

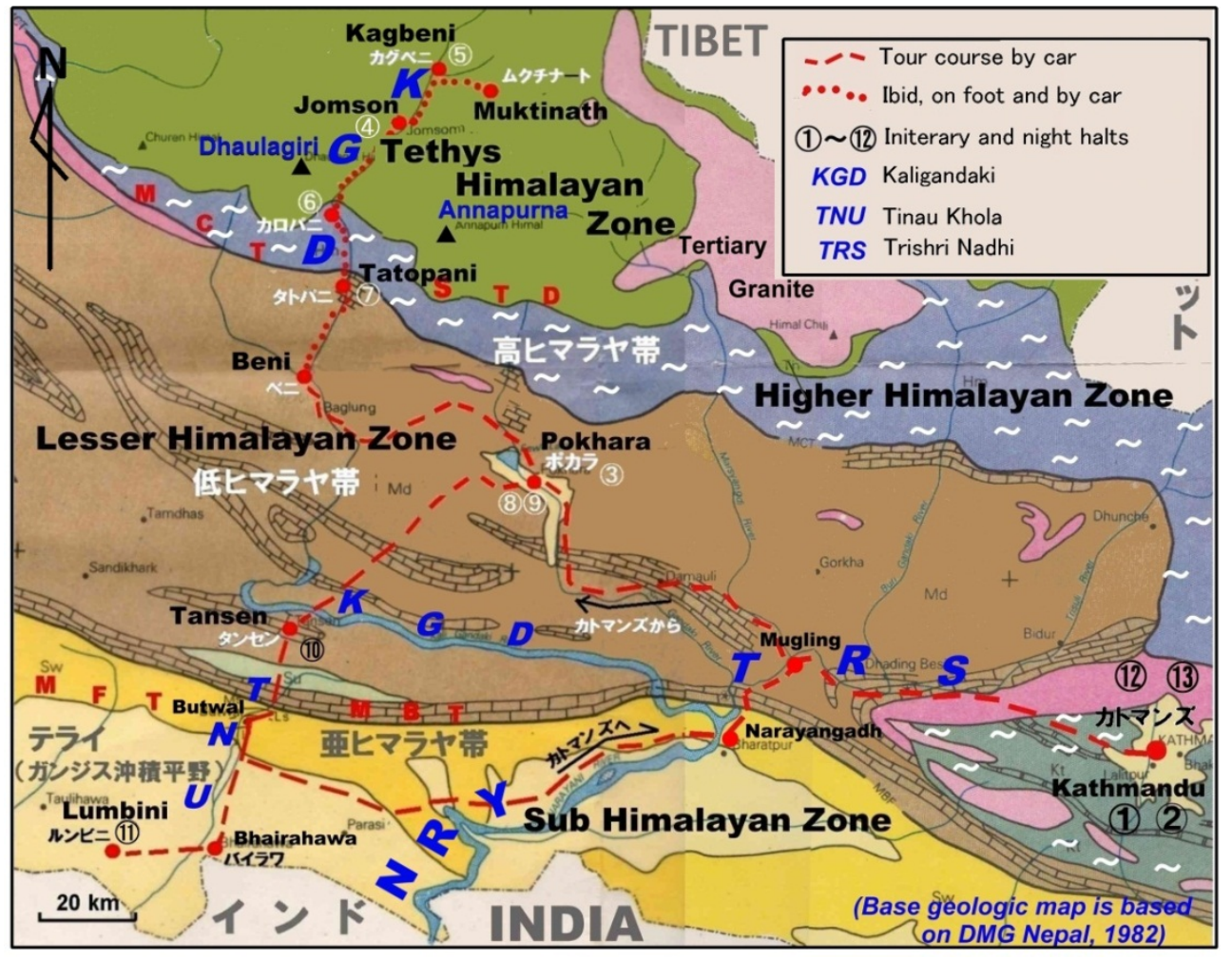

Figure 3. Geologic outline and exercise tour course. KGD: Kaligandaki (river), UNU: Tunau Khola (river), TRS: Trisuri Nadi (river), NRY: Narayani Ganga (river). Circled number: Night halts. Dotted line: Tour course mainly on foot, Dashed line: Tour course mainly by car. (Base geologic map is referred after Department of Mines and Geology, 1982) 
The $150 \mathrm{~km} \mathrm{~N}-\mathrm{S}$ traverse of the Himalaya along the route connecting Kaligandaki and Tinau Khola valleys in west-central Nepal is the best geo-excursion course that exposes a full view of the Himalayan Orogen (Fig. 3). From the north to the south the tour crosses the Tibettan Tethys Himalayan Zone occupied by the Paleozoic to Mesozoic Tethys Sedimentary Sequence (TSS), the South Tibetan Detachment System (STDS), the Higher Himalayan Zone composed of the Higher Himalayan Gneisses (HHG) of mostly late Proterozoic sedimentary sequence origin, the Main Central Thrust (MCT), the Lesser Himalayan Zone occupied mostly by the Middle to Upper Proterozoic Lesser Himalayan Metasediments (LHM) partly by the late Paleozoic to Mesozoic Tansen Group, the Main Boundary Thrust (MBT), the Siwalik Zone (the Sub-Himalayan Zone) composed of the Cenozoic Siwalik Group, the Main Frontal Thrust (MFT), and the Indo-Gangetic Plain (Terai) filled by the Aluvium sediments. Tables 1 and 2 represent simplified stratigraphy of the TSS and the LHM. Beautiful outcrops of all the above geologic zones and boundary thrusts are observable throughout the tour. A variety of Quaternary geological features as well as natural hazards are also observed throughout the tour. Detailed geologic explanations of the traverse and observation points are given by Yoshida and Ulak (2017).
Table 1. Stratigraphy of the Tibethan-Tethys Sedimentarhy Sequence (TSS) in the Kaligandaki Valley area (after Colchen et al., 1980)

\begin{tabular}{|c|c|c|}
\hline \multicolumn{2}{|c|}{ Geologic age } & Formation \\
\hline \multirow{4}{*}{} & Middle Cretaceous & Muding Formation \\
\cline { 2 - 3 } & Lower Cretaceous & Chukh Formation \\
\cline { 2 - 3 } & Upper Jurassic & Spiti Formation \\
\cline { 2 - 3 } & Middle Jurassic & Lumachelle Formation \\
\cline { 2 - 3 } & Lower Jurassic & Jomsom Formation \\
\cline { 2 - 3 } & Upper Triassic & Quartzite Formation \\
\cline { 2 - 3 } & Lower Triassic & Thinigaon Formation \\
\hline \multirow{4}{*}{} & Permo-Carbonferous & Thini Chu Formation \\
\cline { 2 - 3 } & Permo-Carbonferous & Tilicho Lake Formation \\
\cline { 2 - 3 } & Devonian & Tilicho Pass Formation \\
\cline { 2 - 3 } & Silurian & North Face Quartzite Formation \\
\cline { 2 - 3 } & Ordovician & Nilgiri Formation \\
\cline { 2 - 3 } & Ordovician & Pi Formation \\
\cline { 2 - 3 } & Cambrian & Annapurna Yellow Formation \\
\cline { 2 - 3 } & Cambrian & Sanctuaire Formation \\
\cline { 2 - 3 } & &
\end{tabular}

\section{Program of the SHET}

The SHET is conducted by the main responsibility of the Gondwana Institute for Geology and Environment (GIGE, Hashimoto, Japan) in collaboration with the Department of Geology, Tri-Chandra Campus, Tribhuvan University, Kathmandu, Nepal.

Table 2. Simplified stratigraphy of the Lesser Himalayan Metasediments (LHM) in western central and central Nepal

\begin{tabular}{|c|c|c|c|c|c|c|}
\hline \multirow{2}{*}{ Geologic Age } & \multicolumn{3}{|c|}{ Western Central Nepal } & \multicolumn{3}{|c|}{ Central Nepal } \\
\hline & \multicolumn{3}{|c|}{ (Sakai, 1985) } & \multicolumn{3}{|c|}{ (Stocklin, 1980) } \\
\hline $\begin{array}{l}\text { Oligocene-early } \\
\text { Miocene }\end{array}$ & \multirow{5}{*}{\multicolumn{2}{|c|}{ Tansen Group }} & Dumri Formation & & & \\
\hline Eocene & & & Bhainskati Fm & & & \\
\hline $\begin{array}{l}\text { late Cret. - } \\
\text { Paleocene? }\end{array}$ & & & Amille Fm & & & \\
\hline $\begin{array}{c}\text { late Jura - early } \\
\text { Cret. }\end{array}$ & & & Taltung Fm & & & \\
\hline late Carb.-Permian & & & Sisne Fm & & & \\
\hline \multirow{2}{*}{ Early Paleozoic } & \multirow{10}{*}{$\begin{array}{l}\text { Kali Gandaki } \\
\text { Super Group }\end{array}$} & \multirow{2}{*}{$\begin{array}{l}\text { Upper KG } \\
\text { Group }\end{array}$} & $\begin{array}{c}\text { Kerabari } \\
\text { Formation }\end{array}$ & \multirow{10}{*}{$\begin{array}{l}\text { Nawakot } \\
\text { Complex }\end{array}$} & \multirow{2}{*}{$\begin{array}{l}\text { Upper NWK } \\
\text { Group }\end{array}$} & $\begin{array}{l}\text { Robang Frmation } \\
\text { Malekhu Limestone }\end{array}$ \\
\hline & & & Ramdighat Fm & & & Benighat Slates \\
\hline \multirow{8}{*}{ Proterozoic } & & \multirow{6}{*}{$\begin{array}{l}\text { Middle KG } \\
\text { Group }\end{array}$} & Saidi Khola & & \multirow{8}{*}{$\begin{array}{l}\text { Lower } \\
\text { Nawakot } \\
\text { Group }\end{array}$} & Hushdi Beds \\
\hline & & & Formation & & & \multirow{3}{*}{ Dhading Dolomite } \\
\hline & & & Khoraidi Fm & & & \\
\hline & & & Chappani Fm & & & \\
\hline & & & Virkot Fm & & & Nourpul Formation \\
\hline & & & Heklang Fm & & & Dandagaon Phyllites \\
\hline & & \multirow{2}{*}{$\begin{array}{l}\text { Lower KG } \\
\text { Group }\end{array}$} & $\begin{array}{l}\text { Naudanda } \\
\text { Quartzite }\end{array}$ & & & Fagfog Quartzite \\
\hline & & & $\begin{array}{l}\text { Andbi (Kuncha) } \\
\text { Fm }\end{array}$ & & & Kuncha Formation \\
\hline & & & Unconformity & & & Fault boundary \\
\hline
\end{tabular}


The tour course includes the complete traverse of the Himalayan Orogen from the Tethys Himalayan Zone to the Indo-Gangetic Plain as mentioned above, covering the route Kathmandu- Pokhara- Muktinath- Pokhara- TansenButwal- Mugling-Kathmandu in 10 days. Starting from Kathmandu, which lies in the center of the Kathmandu Basin filled by Quarternary sediments covering the Proterozoic Kathmandu Nappe of the Higher Himalayan Zone, the tour runs in the Middle to Late Proterozoic Lesser Himalayan Zone along the Trishuli River and reaches the Pokhara Valley which is again filled by the Quarternary sediments covering the basement LHM. From Pokhara, the tour directly goes to Muktinath, in the upper reaches of the Kaligandaki valley by driving jeeps. Muktinath has the altitude of $3800 \mathrm{~m}$ and is the very holly place of Hinduism. The traverse starts from Muktinath southward by trekking and driving along the Kaligandaki Valley, that flows between the Annapurna and Dhaulagiri ranges both having $8000 \mathrm{~m}$ high peaks. The tour along the Kaligandaki Valley from Muktinath to Pokhara runs within the Tethys Himalayan, the Higher Himalayan, and the Lesser Himalayan zones and is bressed with amazing geology and fantastic scenary of the Himalaya.

The tour starts Pokhara by bus southward to Lumbini via Tansen mostly along the Tinau Khola river within the Lesser Himalayan, Sub Himalayan zones and the Gangetic Plain. Surrounding Tansen, the Gondwana Sequence of the Tansen Group occurs. The course ends at an additional holly place, explicitly Lumbini, the place of the birth of Buddha.

Table 3. Itinerary of the $7^{\text {th }}$ Student Himalayan Exercise Tour in March 2018.

\begin{tabular}{|c|c|c|c|c|}
\hline Days & March & Route & Details & Remarks \\
\hline Day 1 & 4 th & Japan - Kathmandu (Stay) & Via Guangzhou, arrive KTM 22:10 & \\
\hline Day 2 & 5 th & Kathmandu (Stay) & $\begin{array}{l}\text { Pre-tour seminar at TU, and town } \\
\text { excursion escorted by TU students }\end{array}$ & No car necessary \\
\hline Day 3 & 6 th & KTM-PKR (Stay) & $\begin{array}{l}\text { Viewing landslides, colluvium, talus, } \\
\text { terrace, Lesser Himalayan geology, } \\
\text { Krishnavir landslide }\end{array}$ & Bus, with a good quality speaker \\
\hline Day 4 & 7 th & PKR-Jomsom (Stay) & $\begin{array}{l}\text { Some stops viewing Annapurna Range, } \\
\text { Viewing Fagfog quartzite, Kuncha } \\
\text { phyllite, GLOF sediments and terraces }\end{array}$ & Bus, with a good quality speaker \\
\hline Day 5 & 8 th & $\begin{array}{l}\text { Jomsom-car-Muktinath-walk - } \\
\text { Kagbeni (Stay) }\end{array}$ & $\begin{array}{l}\text { Several stops to learn geomorphology } \\
\text { and geology of Quaternary and of } \\
\text { Tethys Sediments. }\end{array}$ & $\begin{array}{l}2 \text { jeeps JOM-MUK. MUK-KAG, one } \\
\text { jeep should ba associated with the } \\
\text { trekking. }\end{array}$ \\
\hline Day 6 & 9th & KGB-car, walk-Kalopani (Stay) & $\begin{array}{l}\text { Tethys Sediments, STDS, FIII of the } \\
\text { Higher Himalayan Gneisse, Morain } \\
\text { hills. Observation and sketches }\end{array}$ & $\begin{array}{l}\text { KGB-JOM: one jeep should be } \\
\text { associated with the trekking. } \\
\text { JOM-MRP, bus should be with us, } \\
\text { making several stops. }\end{array}$ \\
\hline Day 7 & 10th & $\begin{array}{c}\text { Kalopani-car, walk-Tatopani } \\
\text { (Stay) }\end{array}$ & $\begin{array}{l}\text { Higher Himalayan Gneisses, MCT, } \\
\text { Lesster Himalayan Metasediments, } \\
\text { Landslides }\end{array}$ & $\begin{array}{l}\text { Lete-TTP, bus should be with } \\
\text { trekking. }\end{array}$ \\
\hline Day 8 & 11th & TTP - jeeps - PKR (Stay) & $\begin{array}{l}\text { Lesser Himalayan Metasediments, } \\
\text { GLOF sediments, Terraces }\end{array}$ & $\begin{array}{l}\text { TTP-PKR, bus should be with us, } \\
\text { making several stops. }\end{array}$ \\
\hline Day 9 & 12 th & PKR (Stay) & $\begin{array}{l}\text { GLOF sediment, Landslides, Sand } \\
\text { subsidence, Mountain Museum }\end{array}$ & One day city tour by a bus. \\
\hline Day 10 & 13 th & PKR-bus-TAN (Stay) & $\begin{array}{l}\text { Mahabharat Range topography, Lesser } \\
\text { Himalayan Metasediments, Tansen } \\
\text { Group, Palpa Klippe. }\end{array}$ & By the bus, with several stops. \\
\hline Day 11 & 14 th & TAN -bus- Lumbini (Stay) & $\begin{array}{l}\text { Lesser Himalayan Metasediments, } \\
\text { Gondwana Sediments, MBT, Siwaliks, } \\
\text { MFT, Gangetic Plain, Maya Devi } \\
\text { Temple }\end{array}$ & By the bus, with several stops. \\
\hline Day 12 & 15 th & LMB- bus - KTM (Stay) & $\begin{array}{l}\text { MFT, Lesser Himalayan } \\
\text { Metasediments, MBT }\end{array}$ & By the bus, with several stops. \\
\hline Day 13 & 16th & KTM (Stay) & $\begin{array}{l}\text { Summary seminar at TU with TU } \\
\text { students in the morning, free time in } \\
\text { the afternoon.. }\end{array}$ & No car used \\
\hline Day 14 & 17 th & Depart KTM 23:15 & $\begin{array}{l}\text { Visiting world heritage etc in } \\
\text { Kathmandu escorted by TU students. } \\
\text { Departure Kathmandu in late night. }\end{array}$ & Stay on the fight \\
\hline Day 15 & 18 th & Guangzhou-KIX & 5:30 Gugangzhou 8:40 - KIX 13:40 & \\
\hline
\end{tabular}


The itinerary of the SHET-7 in March 2018 is shown on Table 3. The Japanese tour team arrived Kathmandu on the $1^{\text {st }}$ day. On the $2^{\text {nd }}$ day, the pre-tour seminar was conducted at the Tri-Chandra campus in the morning and a city tour was escorted by students of the campus in the afternoon. From the $3^{\text {rd }}$ to the $12^{\text {th }}$ days the bus-jeep tour in the Himalaya as mentioned above took place. On the $13^{\text {th }}$ day we had the summary meeting of the geotour in which all participants reported their fruits from the tour in English. On the $14^{\text {th }}$ day, participants were escorted on the city tour again by the students of the Tri-Chandra campus in the day time and in the night the Japanese team departed Kathmandu for Japan.

All the budget of the tour is covered by the participation fee. The participation fee for a student is generally about 1000 USD which covers all necessary expenses of the tour of 13 days after reaching Kathmandu from Japan. The details of the account of the tour are given above.

\section{Highlights of Field Observations in the Tours from the North to the South}

Because the tour course covers a full traverse of all the geologic zones of the Himalayan Orogen, there are so many important points to observe during the tour. Among them the tour team selected one or two observation point(s) from each geotectonic zones of the Himalaya and from four major boundary faults. Detailed location and description of stops (observation points) are given in the guidebook (Yoshida and Ulak, 2017). Below given are highlights of observations in the tour from the north to the south, starting from the upper reaches of the Kaligandaki Valley.

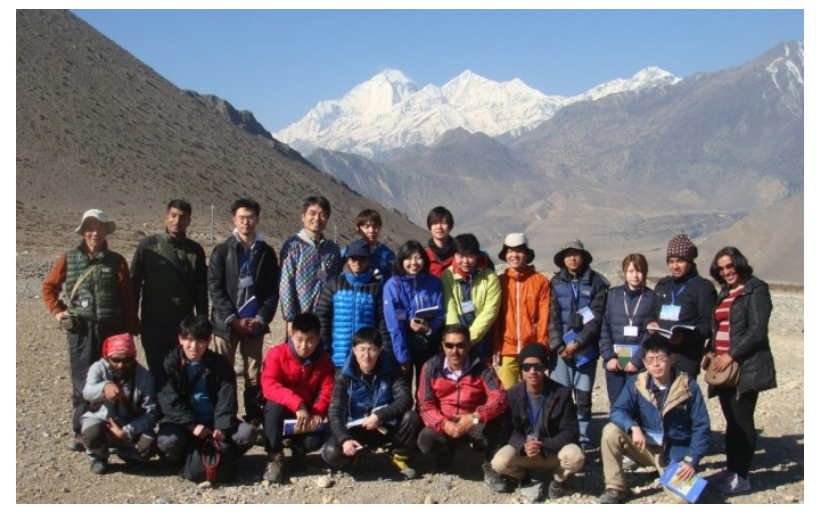

( $7^{\text {th }}$ tour, March 2018).

Figure 4. SHET-7 tour team on the east terrace of Kagbeni with Dhaulagiri range on the back

The first stop is the beautiful scenery on the east terrace of Kagbeni. Here a full view of topographic and geologic characteristics of the Tethys Himalayan Zone is met with.
At this locality, a distant view to the snow-covered Himalayan ridges including the Dhaulagiri range is observed (Fig. 4). The first major outcrop is the Jurassic Spiti Formation which provides good possibilities for ammonite fossil hunting, and therefore, is very interesting and fruitful for participants (Fig. 5).

Observation of large-scale recumbent folds of the Tethys Sedimentary Sequence (TSS) is the highlight in the Tethys Himalayan Zone, among which those observed on the eastern slope of the Dapudon ridge (Fig. 6) are superb fantastic. At the location of the South Tibetan Detachment System (STDS), we can observe a general view of the system situated along the Chhaktan Khola (Fig. 7), and then after a good outcrop of a part of the STDS composed of calcareous sandstone of the TSS intruded by Tertiary leucogranite (Fig. 8). A beautiful fold structure of the TSS is also viewed on the southeastern slope of the Dhaulagiri Range. These structures are almost identical with the sketch of T. Hagen (1968) which shows folded lower TSS, STDS and the HHG (Fig. 9).

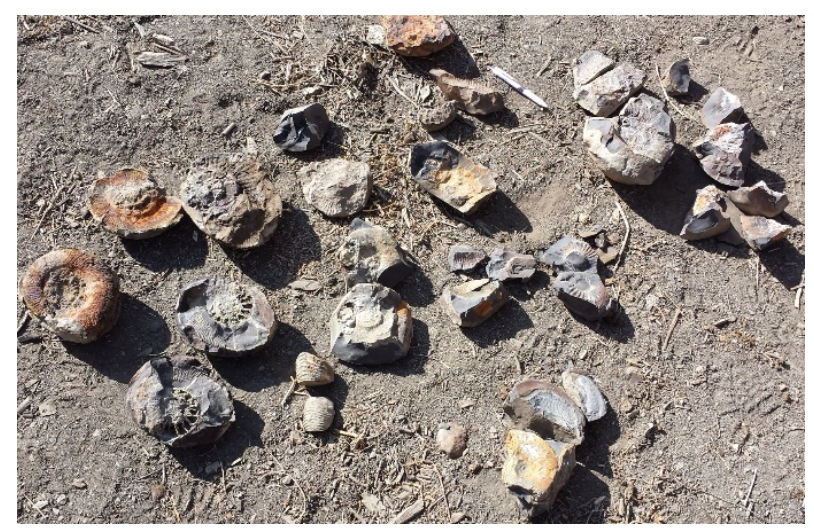

Figure 5. Ammonite fossils collected by students from the late Jurassic Spiti Formation, west of Muktinath ( $5^{\text {th }}$ tour, March 2016).

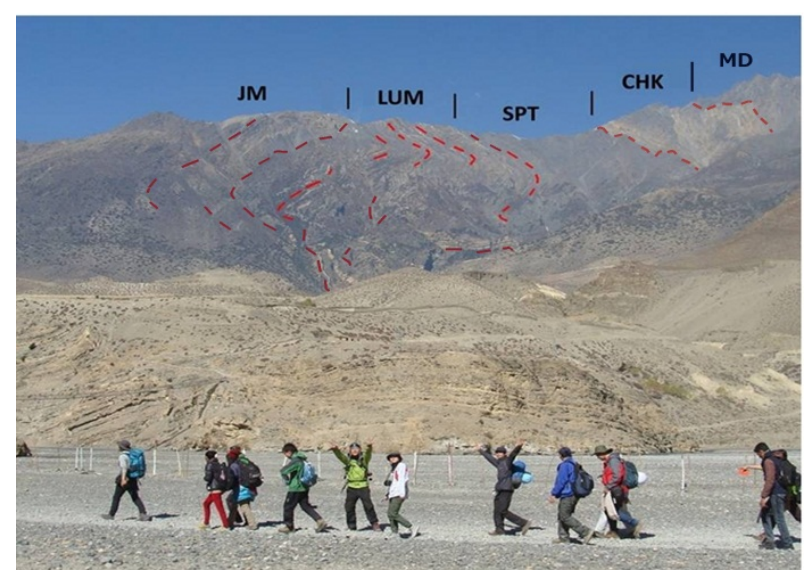

Figure 6. Students enjoy walking on the gravel of the Kaligandaki Valley. Beautiful folding of most of Mesozoic Tethys formations are seen on the mountain slope (5th tour, March 2016) . JM: Jomsom Formation, LUM: Lumachalei Formation, SPT: Spiti Formation, CHK: Chukh Formation, MD: Muding Formation. 


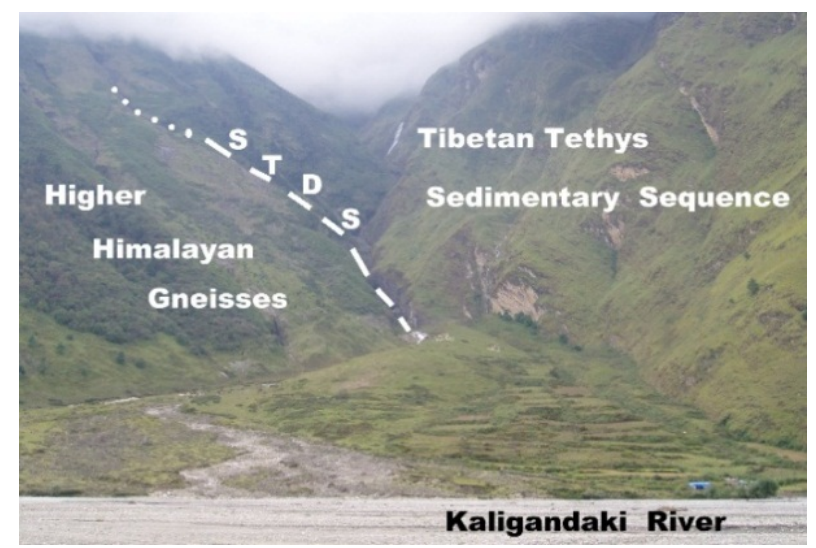

Figure 7. Chhacktan Khola, the STDS valley. A detailed description of the outcrop in the valley is given in the guidebook (Yoshida and Ulak, 2017).

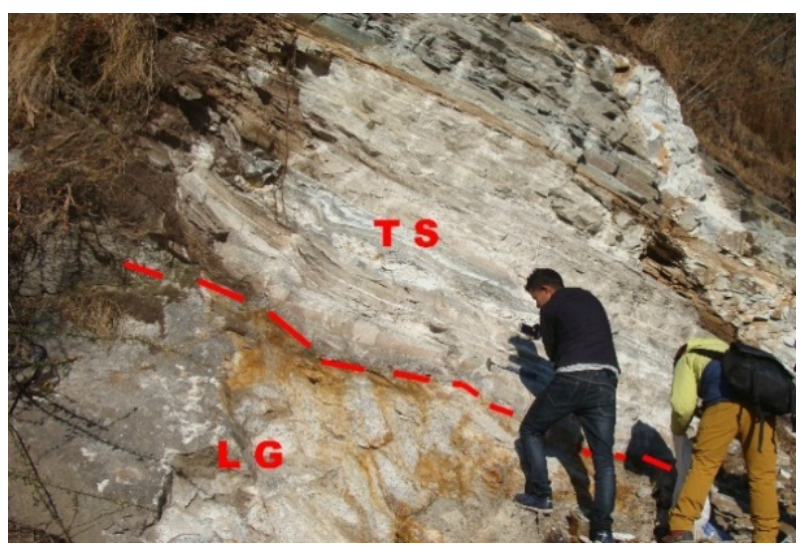

Figure 8. A newly found outcrop of STDS. TS: Calcareous sandstone of the TSS, LG: Tertiary leucogranite ( $7^{\text {th }}$ tour, March 2018).
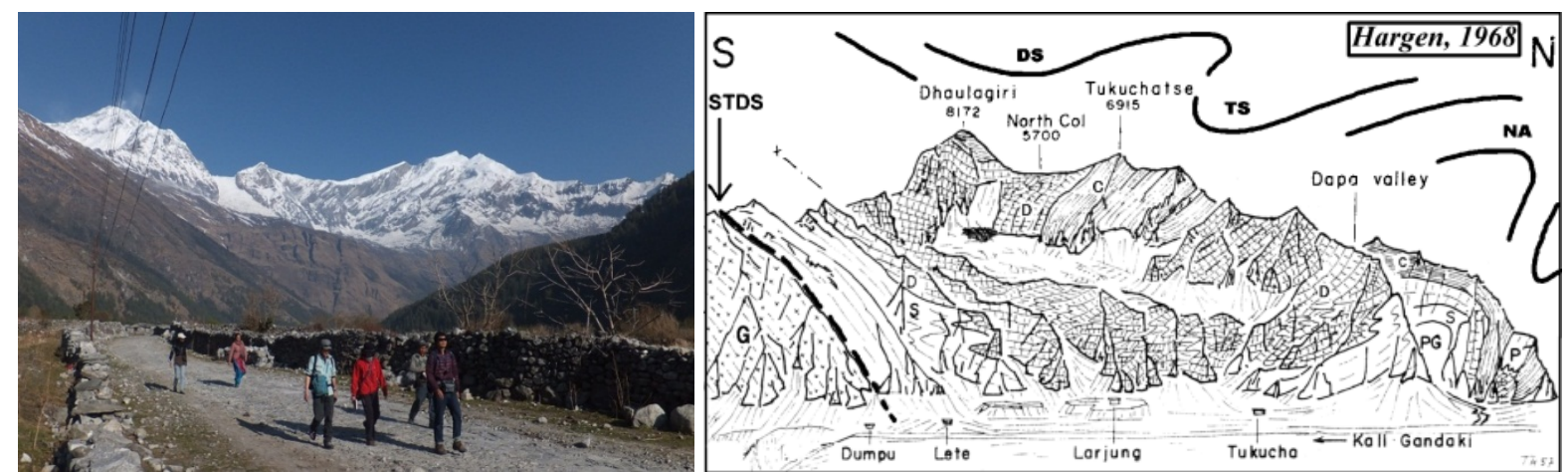

Figure 9. Trekking below Dhauragili Range (2nd Tour, March 2013). G: Rocks of the HHG, DS: Dhaulagiri Syncline, TS: Tukuche Syncline, NA: Nilgiri Anticline.
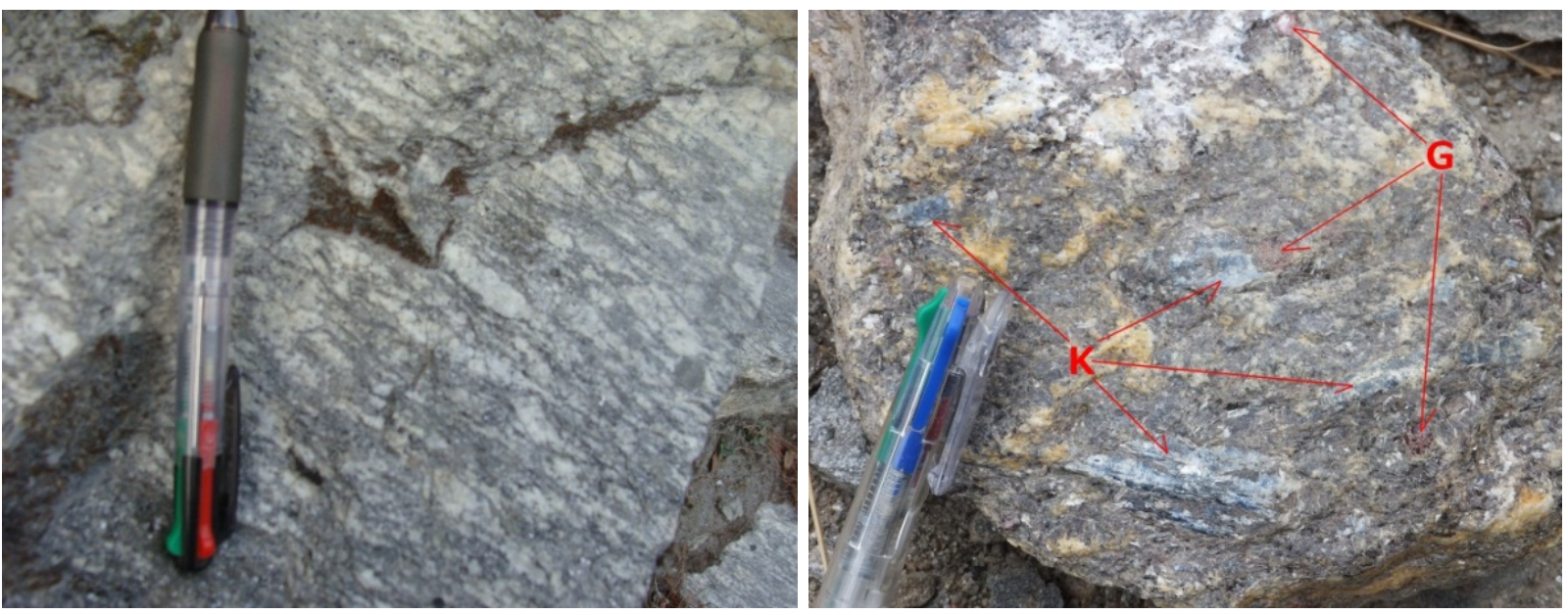

Figure 10. Augen gneiss (left) and kyanite (K)-garnet (G) gneiss (right) of the Higher Himalayan Gneisses. 
In the Higher Himalayan Zone, beautiful augen gneiss, kyanite-garnet gneiss, sillimanite-garnet gneiss etc. of the HHG are observed (Fig10). At the Main Central Thrust (MCT), a variety of mylonitic, phyllonitic, and sheared rocks of both gneiss and phyllite origin (Fig. 11) is observed.

Just south of MCT, we came across a hot spring at the Tatopani village and can enjoy it (Fig. 12). The heat source of the hot spring is regarded to be the MCT movement. Just south of the Tatopani village, a good example of rock slide (slope failure) on the left bank and its debris still remaining on the river floor of the Kaligandaki valley are observed (Fig. 13). Phyllite and slate of the Kuncha Formation (Fig. 14) of the HM form most of outcrops of the Lesser Himalayan Zone appearing all along the course to the south of Tatopani up to Pokhara. Before arriving Pokhara surrounding Baglung, a tremendous amount of fluvial sediments are present, most of which are possibly of the glacial flood overburst flood (GLOF) origin, forming a wide and high (reaching up to ca 200-300m above the river floor) terrace (Fig. 15).

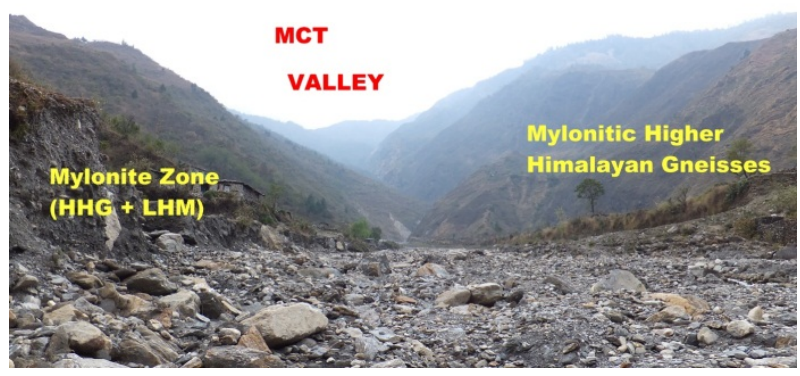

Figure 11. The MCT Ghatte Khola (above) and phyllonite (right) Characteristics of MCT. Gravels are mostly mylinitic and phyllonitic rocks and gneissic and granitic rocks.

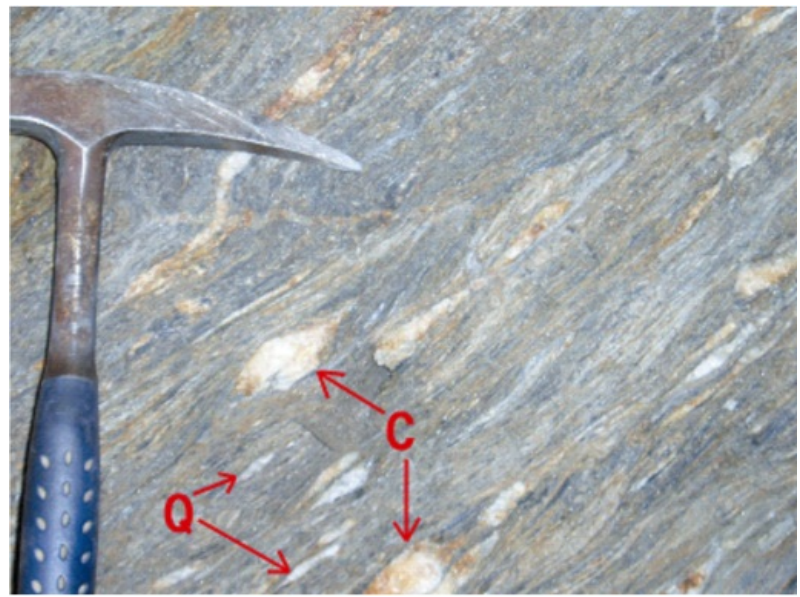

A photo of phyllonite derived possibly from a mixture of phyllite and granitic gneiss. Q: Deformed quartz pods. C: Deformed clasts rich in quartz-feldspathic minerals.

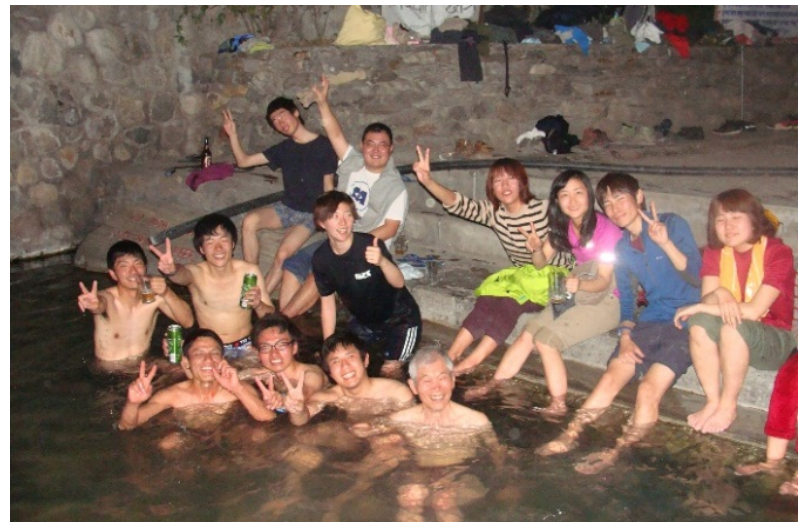

Figure 12. Students enjoy the open spa in Tatopani at the end of trekking (5th tour, 2016). 


\section{Tatopani Rockslide}

In 1998, the left bank slope of Kaligandaki collapsed and the debris dammed the valley forming a lake.

The Tatopani village was mostly submerged in the lake for 7 hours.

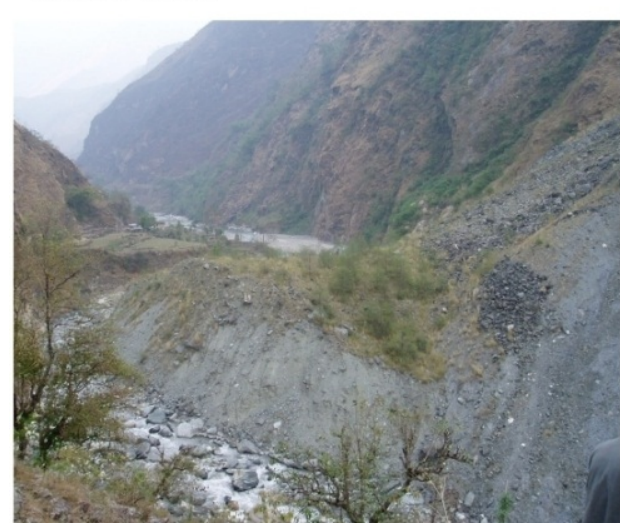

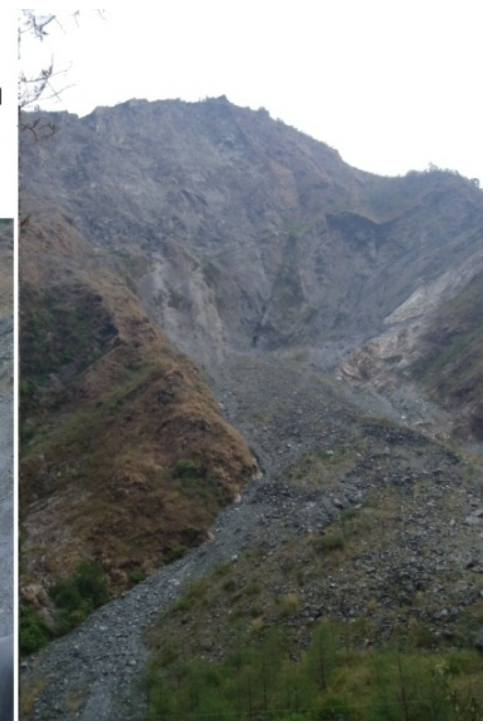

Figure 13. Rockslide of 1998 south of Tatopani, looking toward north. Here the dark rock is gabbro amphibolite and the light gray rock is quatzite of the Naudanda Quartzite of the LHM.

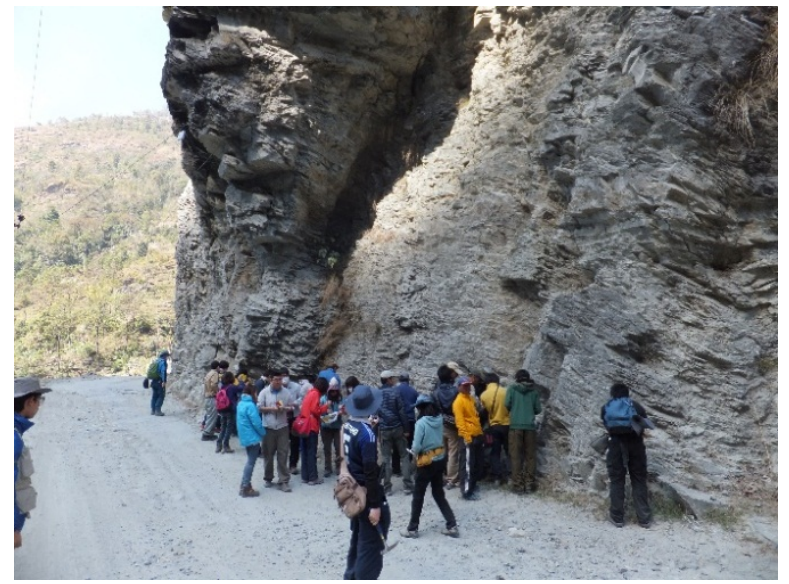

Figure 14. A large outcrop of phyllite of the Kuncha Formation south of Tatopani ( ${ }^{\text {rd }}$ tour, March 2014).

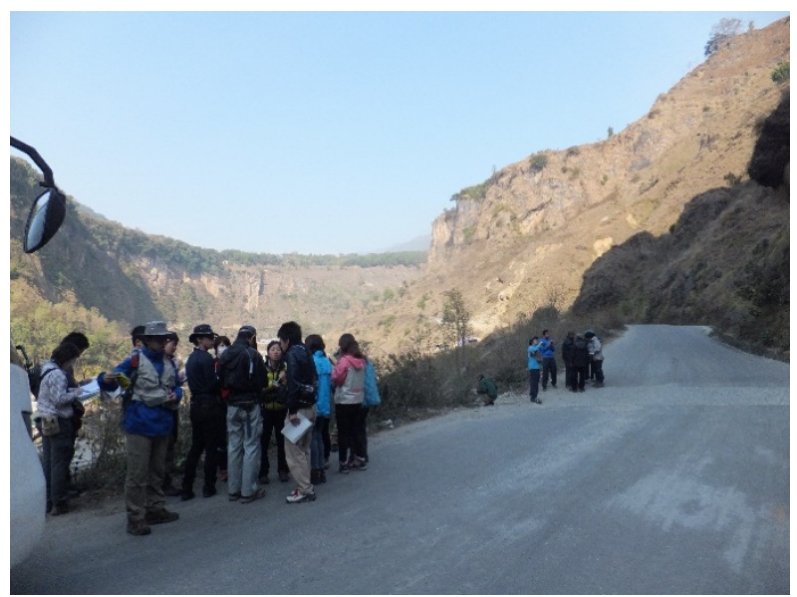

Figure 15. Tremendous thick fluvial sediments surrounding Baglung. The sediments includes much amount of GLOF sediments. $\left(3^{\text {rd }}\right.$ tour, March 2014). 


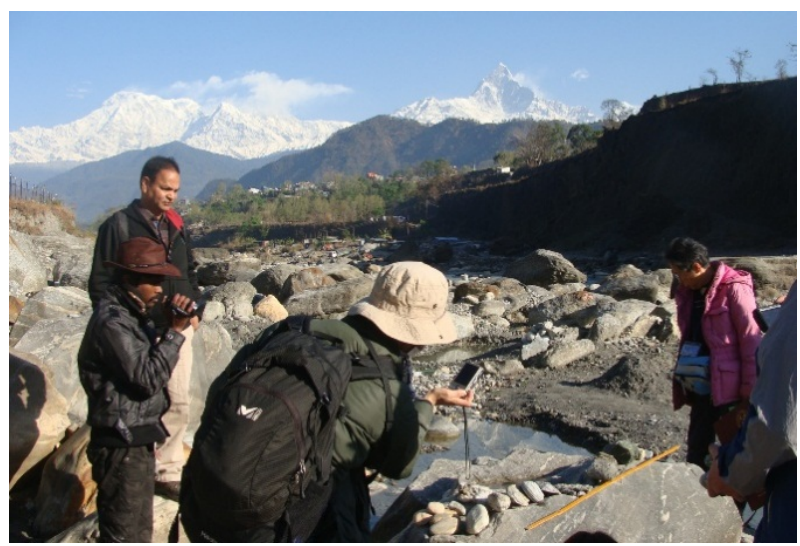

Figure 16. River gravel observations on the Seti Khola river, Pokhara, with the Beautiful Annapurna Range on the background (6 $6^{\text {th }}$ tour, March 2017). Here, all varieties of Himalayan rocks are possible to observe and collect.

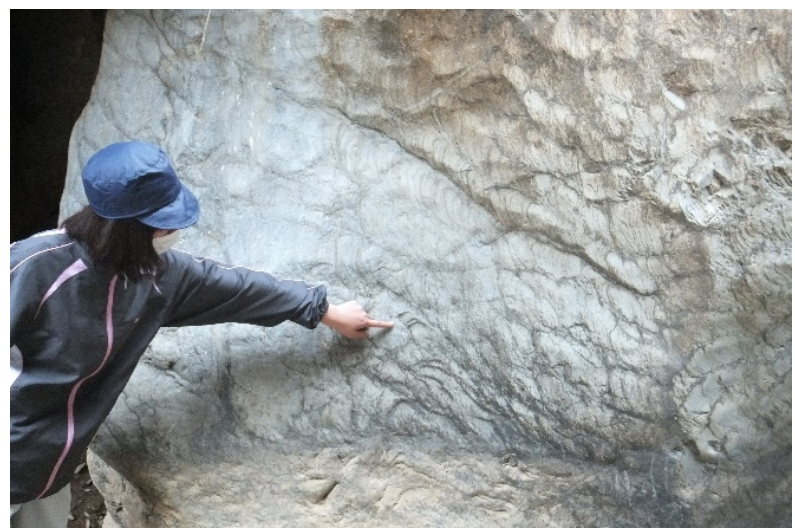

Figure 17. A large dolomite boulder of the LHM rich in Stromatolite fossils, south of Ramdhi (3rd tour, 2014).

In Pokhara, students can enjoy observing present river gravels of the Seti Khola river composed of a variety of rocks as well as the fantastic view of the Annapurna Range (Fig. 16). Along the rout from Pokhara to Tansen, a variety of sedimentary formations composing the LHM are distributed. Students are interested in beautiful stromatolite fossils on river boulders (Fig. 17) surrounding Ramdi town where the tour again meets the Kaligandaki valley.

Surrounding Tansen and to the south onwards, the Mesozoic to Cenozoic Tansen Group forms the most of outcrops (Fig. 18). Here all the stratigraphic units of the Tansen Group are met with. Moreover, the interesting geologic structures representing the nappe and thrust tectonics including the Palpa klippe along Tinau Khola is observed.

In the lower reaches of the Tinau Khola river, the tour crosses the Main Boundary Thrust (MBT) which are clearly viewable on the mountain slope of the right bank of the river (Fig. 19). To the south of the MBT, we enter the Siwalik Zone composed of the Plio-Pleistocene Siwalik Group composed of clastic sedimentary rocks. We can observe very good outcrops all along the road (Fig. 20).

In Butwal which is situated at the southern foot of the Siwalik Range, a beautiful topographic expression of the Main Frontal Thrust (MFT) is observed (Fig. 21). The tour team generally takes a night halt in Lumbini and visit the Maja Devi Temple, the birth place of holly Buddha (Fig.22). 


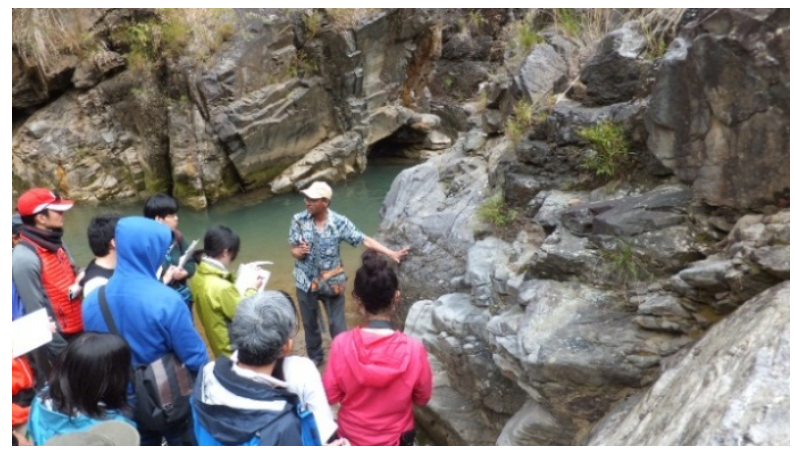

Figure 18. Rocks of the Tansen Group occurring on the river floor of Tinau Khola, south of Tansen ( $4^{\text {th }}$ tour, March 2015).

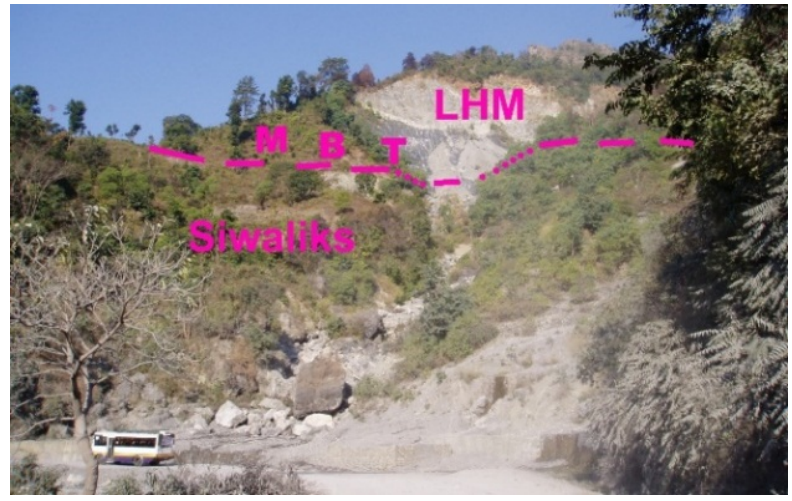

Figure 19. The exposure of the MBT along the Tinau Khola north of Butwal.

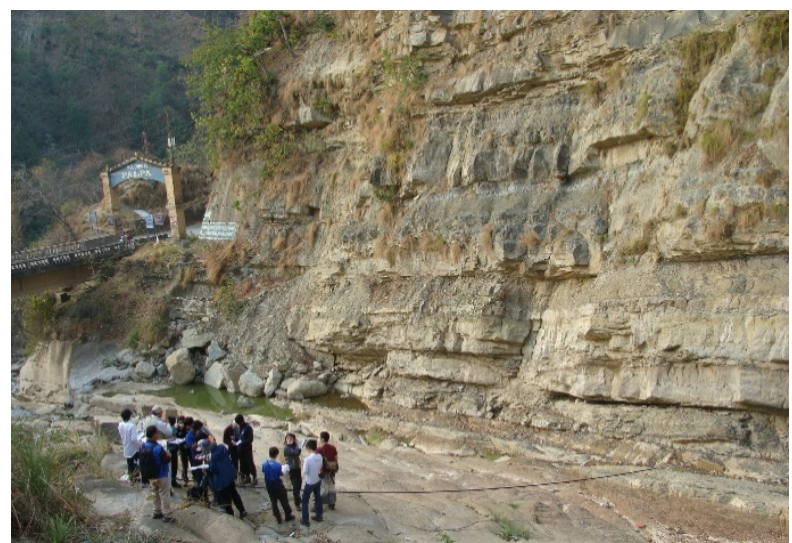

Figure 20. Observing the lower strata of the Siwalik Group, along the Tinau Khola raod (3rd tour, March 2014).

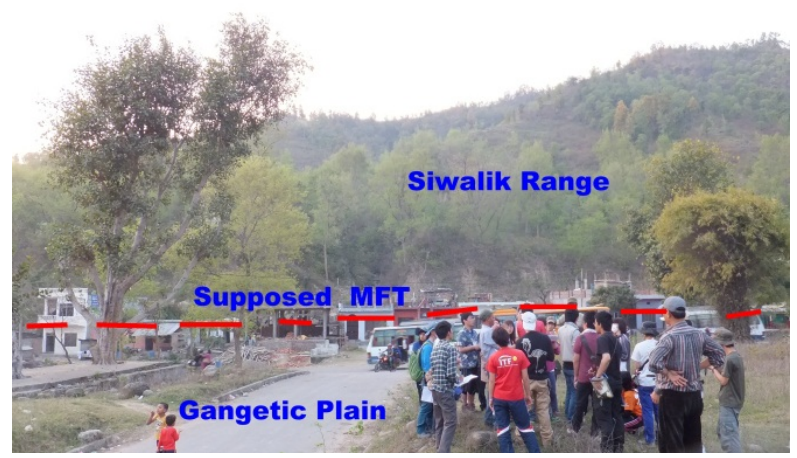

Figure 21. Main Frontal Thrust (MFT), the Siwaliks and the Gangetic Plain (Right, 3rd tour, March 2014). 


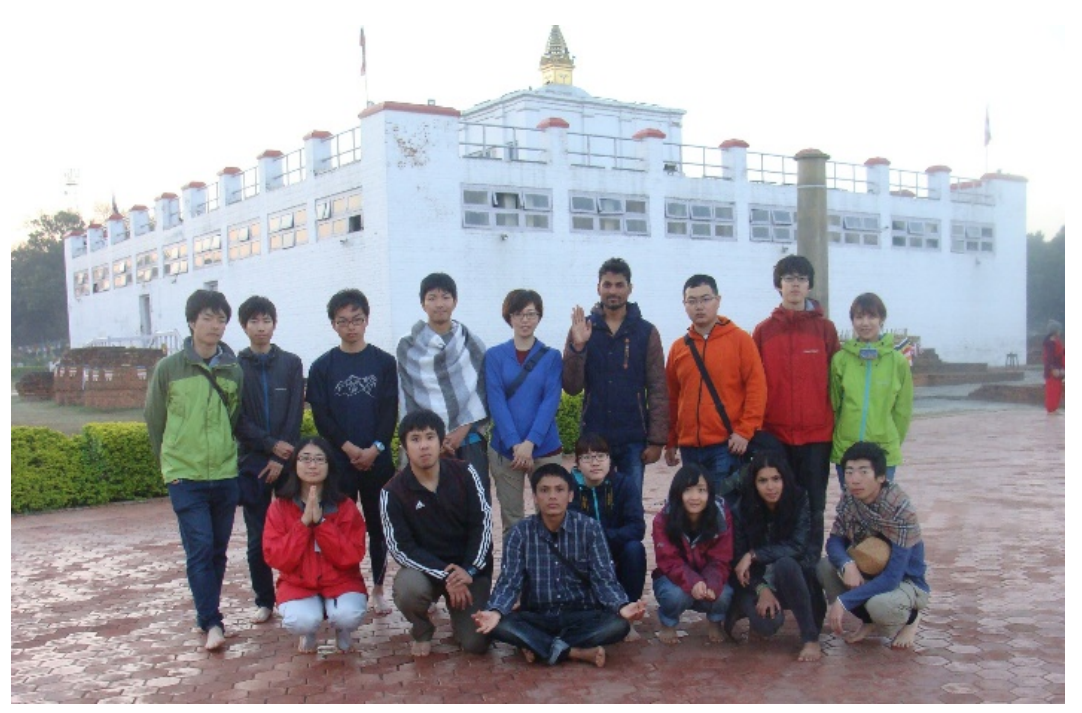

Figure 22. Students are impressed to be at the birth place of Gautama Buddha (5th tour, March 2016)

\section{Report of the SHET Programs and Tours}

A simple report of the exercise tour of each year has been disclosed on the SHET home page every year, soon after finishing the exercise tour, and published in The Geological Society of Japan News as well. Participants of an exercise tour are requested to submit a summary report of their participation to the tour, either fully in English or in Japanese with an English abstract. All these reports were assembled to form a report book with the title, e.g., Traversing the Himalayan Orogen 2018 (e.g., Yoshida, 2018) which carry not only the above reports but also formal report by the organizer and reports by leaders, as well as important data on the SHET program of the year. The book is disclosed on the SHET home page and has been made open to world book market.

A summary report of the SHET program so far conducted and a report of the exercise tour of a year were dispatched since 2012 every year at meetings of several academic societies including The Geological Society of Japan, Association for the Geological Collaboration in Japan and International Association for Gondwana Research, and Symposium on Polar Sciences (e.g., Yoshida et al., 2018, Yoshida and Student Himalayan Exercise Project, 2018) as well. A full information on the SHET programs of 2012-2016 was summarized and published in five Japanese reports (Yoshida, 2014,2015, 2016a, b, c).

\section{Participants of the Past 7 Exercise Tours}

Number of participants of the SHET of past 7 years were 14-5-25-21-15-19-16 (Table 4), varied from 2012-2018. The number of participants of the $2^{\text {nd }}$ tour was the least (5 participants) among the 7 tours due to no group participation, and the $3^{\text {rd }}$ tour included the largest number of participants (25 participants) due to the group participation of the Shimane University. 
Table 4. Participants of the SHET each year

\begin{tabular}{|c|c|c|c|c|c|c|c|c|c|c|c|c|c|c|c|c|}
\hline \multirow{2}{*}{ Affiliation etc } & \multicolumn{6}{|c|}{ Number of members each year } & \multicolumn{8}{|c|}{ Class etc } & \multicolumn{2}{|c|}{ Gender } \\
\hline & 2012 & 13 & 14 & 15 & 16 & 17 & 1 & 2 & 3 & 4 & $M C$ & $D C$ & Citi-zen & Tea- cher & $M$ & $F$ \\
\hline Akita U & & & & 1 & & & & & & & 1 & & & & & 1 \\
\hline Niigata $U$ & & & & & 1 & & 1 & & & & & & & & & 1 \\
\hline Ibaraki U & & & & & 1 & & & & & 1 & & & & & 1 & \\
\hline Tsukuba U & & 1 & 1 & & 1 & & & & & 1 & & 2 & & & 2 & 1 \\
\hline Tokyo U & & & 2 & & & 1 & & 1 & & & 2 & & & & 2 & 1 \\
\hline Meiji U & & & & & & 1 & & & & & & 1 & & & 1 & \\
\hline Nihon U & & & & & & 1 & & & & 1 & & & & & & 1 \\
\hline Shizuoka U & & & 1 & & & & & & & 1 & & & & & 1 & \\
\hline Shinshu U & & 1 & & 10 & 6 & 1 & & 15 & 3 & & & & & & 13 & 5 \\
\hline Nagoya U & 3 & & & 1 & 1 & & & & 3 & 1 & 1 & & & & 5 & \\
\hline Chiba U & 1 & & & & 2 & & 1 & & 1 & 1 & & & & & 3 & \\
\hline Osaka C U & & & & & & 1 & & 1 & & & & & & & & 1 \\
\hline Shimane U & 7 & & 14 & 5 & & 7 & & 21 & 5 & 1 & 5 & & 1 & & 21 & 12 \\
\hline Yamaguchi U & & & 3 & & 1 & & 1 & & 1 & & 2 & & & & 3 & 1 \\
\hline Kyushu U & & & & 1 & & & & & 1 & & & & & & & 1 \\
\hline Ryukyu U & 1 & & & 1 & & & & 1 & & 1 & & & & & 2 & \\
\hline Highschool & & 1 & & & & & & & & & & & 1 & & & 1 \\
\hline Citizen & & & 2 & & & 2 & & & & & & & 4 & & 1 & 3 \\
\hline Tribhuvan U & 2 & 1 & 2 & 2 & 2 & 2 & & 5 & 2 & 4 & & & & & 5 & 6 \\
\hline Nepal Citizen & & 1 & & & & & & & & & & & 1 & & & 1 \\
\hline Kerala U & & & & & & 2 & & & & 2 & & & & & 2 & \\
\hline Sum & 14 & 5 & 25 & 21 & 15 & 18 & 3 & 44 & 16 & 14 & 11 & 3 & 7 & & 62 & 36 \\
\hline JPN Teacher & 2 & 1 & 2 & 1 & 1 & 2 & & & & & & & & 9 & 9 & \\
\hline TU Teacher & 1 & 1 & 2 & 2 & 1 & 1 & & & & & & & & 8 & 8 & \\
\hline Grand Sum & 17 & 7 & 29 & 24 & 17 & 21 & 3 & 44 & 16 & 14 & 11 & 3 & 7 & 17 & 79 & 36 \\
\hline
\end{tabular}

The total number of participants for 7 years included 106 students including 91 undergraduate and 15 master and doctoral course students from 20 universities, 1 high school girl and 8 citizens, in addition to 19 teachers/leaders from Japan and Nepal. Throughout the 7 years, number of Japanese students who did not belong a group and joined individually was 5-3-7-4-7-5-11 for the $1^{\text {st }}, 2^{\text {nd }}, 3^{\text {rd }}, 4^{\text {th }}, 5^{\text {th }}$, $6^{\text {th }}$ and $7^{\text {th }}$ tours respectively. Group participations from two universities (Shimane and Shinshu universities) have thus been very much appreciated for the proper fulfilment and continuation of the SHET program by 2017 , because a small number of participants results in higher participation fee and creating difficulty in maintaining the SHET program. Students participated individually should be encouraged further, for the continuation and development of the SHET program. For the SHET-8 of March 2019, we found that the advertisement and/or encouragement through SNS by students who joined the past SHETs affected over half participants to be interested to join the SHET-8.

\section{Expense of the Past 7 Exercise Tours.}

The expense of the SHET should be economical as far as possible. So, the simplicity, along with the safety and cleanness have been the motto throughout the tours of 7 years. The expense of the tour includes A) airfare Japan-Kathmandu, B) lodgings and meals, C) local transportation as the major parts and D) preparation for the tour, E) taxes such as VISA and trekking permit, F) stay and meals at transit airports, and G) other miscellaneous ones.

As for A), to obtain an economical ticket, order of purchase should be made as early as possible, as for B) and C), comparative assessment of quotations given by several trekking companies in Nepal was made. Details of expenses of 7 tours from 2012 to 2018 are summarized in Table 3 .

The participation fee including the air fare Japan-Nepal for one student varied from 133,531 JPY (SHET3) to 
190,000 JPY (SHET-2), with the average of 162,492 JPY for 7 years.

The participation fee, which is the practical payment of a student was a little less than the sum of the practical expense for each year. This is due to some contribution by the organizer and citizen participants, the participation fee of a citizen is settled 50000 JPY higher than that of student, to help students to lessen their participation fee.

\section{Fruits of the Student Himalayan Exercise Tours: Conclusion}

\subsection{Fruits Related to Geoscience}

Throughout the 7 SHETs, participants learned the ways of safe and effective geological field survey, of observation and identification of rocks, geological units, geologic structures, natural hazards and topography, as well as got the understanding on the principal geologic structure of the Himalayan Orogen. In addition, they should have become familiar to field geology, and felt the common signature of geology of the Himalaya and Japan, and understood the importance of geology for the human beings and the necessity of further sincere study on geology.

\subsection{Fruits Apart from Geosciences}

Participants experienced meeting different cultures and attitude of students of other universities and countries, and became familiar to English reading and conversation. An English guidebook for the tour was given to participants some months before the tour and pre- study on it was requested. During the field tour, the guidebook was used at every stop, and all participants were obliged to open its pages. In addition to that, daily English communication with foreign students and teachers prompted participants to become familiar to English communication. Group city tours with students of the Tri-Chandra Campus conducted on the first and last days of the tours also facilitated participants to get the familiarity to approach English speaking people. All these experiences should have become the first step for the participants to develop their internationality. Some students even reported that their ideas on the way of living in future have now drastically changed due to the experience of the tour.

Table 5. Costs of the Student Himalayan Exercise Tour, 2012 2018 (JPY)

\begin{tabular}{|l|c|c|c|c|c|c|c|}
\hline $\begin{array}{l}\text { Years and (Number of } \\
\text { Japanese student } \\
\text { participants) }\end{array}$ & $2012(12)$ & $2013(3)$ & $2014(23)$ & $2015(19)$ & $2016(13)$ & $2017(11)$ & $2018(12)$ \\
\hline Air ticket & 81,980 & 56,293 & 56,196 & 72,324 & 69,601 & 59,780 & 60,461 \\
\hline Lodging and meal & 30,241 & 75,727 & 31,833 & 43,089 & 42,944 & 42,738 & 55,131 \\
\hline Local transportation & 21,715 & 36,951 & 23,125 & 25,636 & 34,308 & 35,733 & 40,500 \\
\hline Guide and sherpas & 1,676 & 4,554 & 892 & 3,949 & 4,432 & 2,633 & 3,292 \\
\hline $\begin{array}{l}\text { Tax (VISA and trekking } \\
\text { permit etc) }\end{array}$ & 5,848 & 7,539 & 6,536 & 7,206 & 6,965 & 6,707 & 7,876 \\
\hline Preparation & 16,851 & 24,980 & 8,542 & 11,355 & 25,169 & 18,069 & 21,547 \\
\hline China stays & 0 & 8,929 & 5,011 & 5,224 & 4,891 & 5,883 & 0 \\
\hline Miscellaneous & 3,544 & 7,345 & 4,079 & 434 & & 2,422 & 833 \\
\hline $\begin{array}{l}\text { Margin of Nepale trekking } \\
\text { agency }\end{array}$ & 0 & 7,469 & 2,307 & 3,634 & 4,615 & 3,273 & 4,686 \\
\hline \multicolumn{1}{|c|}{ SUM } & 161,855 & 229,787 & 138,521 & 172,851 & 192,925 & 177,238 & 194,326 \\
\hline $\begin{array}{l}\text { Average partipation fee of } \\
\text { a Japanese student }\end{array}$ & 158,638 & 190,000 & 133,531 & 166,937 & 176,659 & 146,523 & 165,159 \\
\hline
\end{tabular}

7 years average: 162,492 JPY 


\section{REFERENCES}

[1] Department of Mines and Geology, Nepal, 1982, Geological map of Nepal, 1:1,000,000. Harris, N. and Whalley, J., 2001, Mountain building. Block 4. The Open University, UK., 165 pages.

[2] Colchen, M., Le Fort, P. and Pecher, A., 1980, Carte geologique Annapurna-Manaslu-Ganesh, Himalaya du Nepal Echelle 1:200,000. Centre National de la Recherche Scientifique, Paris.

[3] Hargen, T., 1968, Report on the geological survey of Nepal, Geology of the Thakkhola. Memoires de la soc. Helvetique des sci. naturelles, v. 2, 165 p.

[4] Harris, N. and Whalley, J., 2001, Mountain building. Block 4. The Open University, U.K., 165p.

[5] Sakai, H., 1983, Geology of the Tansen Group of the Lesser Himalaya in Nepal. Mem. Fac. Sci., Kyushu Univ., Ser. D, Geology, v. 25, 27-74.

[6] Sakai, H., 1985, Geology of the Kali Gandaki Supergroup of the Lesser Himalayas in Nepal. Mem. Fac. Sci., Kyushu Univ., Ser. D, Geology, v. 25, 337-397.

[7] Searle, M., Simpson, R.L., Law, R.D., Parrish, R.R. and Waters, D.J., 2003, The structural geometry, metamorphic and magmatic evolution of the Everest massif, High Himalaya of Nepal-South Tibet. J. Geol. Soc., London, v. $160,345-366$.

[8] SHET-HP, 2018, Student Himalayan Exercise Project web site. http://www.geocities.jp/gondwanainst/geotours/Studentfiel dex index.htm

[9] Stocklin, J., 1980, Geology of Nepal and its regional frame. J. Geol. Soc., London, 137, 1-34.

[10] Upreti, B.N. and Yoshida, M., 2005, Guidebook for Himalayan Trekkers, Ser. 1, Geology and Natural Hazards along the Kaligandaki Valley, Nepal.

[11] Yoshida, M., 2014a-2017a, The Student Himalayan Exercise Program (in Japanese), I, II, III, IV, V. Earth Science Education and Movement, (73) 57-62, (74) 63-70, (75) 71-77, (76) 89-96, (77) 80-87.

[12] Yoshida, M., (Ed.), 2018, Traversing the Himalayan Orogen 2018: Report of the seventh Student Himalayan Exercise Tour in March 2018 (E-book). Field Science Publishers, Hashimoto, Japan, 189 pages.

[13] Yoshida, M. and Student Himalayan Exercise Project, 2018, Attractive Himalayan Geology: Summary of the student exercise program 7 years and invitation to the 8th tour in March 2019. Poster presentation at Symposium on Polar Science, Dec. 2018, Tachikawa.

[14] Yoshida, M. and Ulak, P.D. (Eds), 2017b, Geology and Natural Hazards along Kaligandaki and Highways Kathmandu-Pokhara-Butwal-Mugling. Guidebook for Student Himalayan Exercise Tour. GIGE Misc. Pub. 35, Field Science Publishers, 144 pages.

[15] Yoshida, M. and Upreti, B.N. (Eds.), 2014, Guidebook for Himalayan Trekkers, Ser. 1, Provisional Second Edition, GRG/GIGE Misc. Pub. 27, Field Science Publishers, 141 pages.

[16] Yoshida, M., Upreti, B.N., Rai, S.M., Bhattarai, T.N., Ulak, P.D., Gajurel, A.P., Dahal, R.K., Dhakal, S., Koirala, M.P., 2008, Field excursion guidebook series on geology and natural hazards in Nepal Himalaya. Proc. Internl' Conf. Management of Landslide Hazard in the Asia-Pacific Region, The Japan Landslide Soc., Tokyo, 335-344.

[17] Yoshida, M., Arita, K., Sakai, T., Paudel, M.R., and Upreti, B.N., 2018, Traversing the Himalayan Orogen-Report of the 7th Student Himalayan Exercise Tour in March 2018-. Poster presentation at 15th International Symposium on Gondwana to Asia, 2018 Annual Convention of IAGR, Xian, China. 